\title{
ANALISIS DEFORMASI PERMUKAAN MENGGUNAKAN METODE DInSAR (Differential Interferometry Synthetic Aperture Radar) PADA STUDI KASUS GEMPABUMI LOMBOK PERIODE AGUSTUS 2018
}

\section{ANALYSIS OF SURFACE DEFORMATION USING DInSAR METHOD (Differential Interferometry Synthetic Aperture Radar) IN CASE STUDY LOMBOK EARTHQUAKES ON AUGUST 2018}

\author{
Muhammad Fikri Azhari $^{1^{*}}$, Karyanto ${ }^{2}$, Syamsurijal Rasimeng ${ }^{3}$, Bagus Sapto Mulyanto ${ }^{4}$ \\ ${ }^{1234}$ Teknik Geofisika Universitas Lampung; Jl. Soemantri Brodjonegoro No 1 Gedong Meneng, Bandar \\ Lampung; telp (0721) 704947
}

Received: 2020, $10^{\text {th }}$ May Accepted: 2020, $18^{\text {th }}$ June

Keyword:

Deformation;

DInSAR;

Earthquake;

Line of Sight;

Lombok.

Corespondent Email:

fikriazharimuhammad@gmail.com

How to cite this article:

Azhari, M.F., Karyanto, Rasimeng, S., \& Mulyanto, B.S. (2020).

Analisis Deformasi Permukaan Menggunakan Metode DInSAR (Differential Interferometry Syntethic Aperture Radar) Pada Studi Kasus Gempabumi Lombok Periode Agustus 2018. Jurnal Geofisika Eksplorasi, 6(2), 131-144.

\begin{abstract}
Abstrak. Lombok terletak pada batas lempeng tektonik aktif, hal ini yang menyebabkan terjadinya gempabumi Lombok pada periode Agustus 2018. DInSAR merupakan teknologi penginderaan jauh yang memanfaatkan satelit radar untuk mengukur besarnya deformasi di permukaan tanah dengan ketelitian sub-sentimeter. Penelitian ini bertujuan untuk memperoleh nilai deformasi permukaan pasca terjadinya gempa yang melanda kawasan Lombok yaitu gempa 5 Agustus 2018 \& gempa 19 Agustus 2018 dan menganalisis karakteristik deformasi yang terjadi pada dua gempa tersebut. Adapun penelitian ini dilakukan berdasarkan pengolahan citra SAR Sentinel-1 menggunakan Software SNAP, Google Earth dan ArcGIS 10.3. Deformasi yang terjadi pasca gempa Lombok 5 Agustus 2018 menyebabkan kenaikan muka tanah (uplift) di pesisir Lombok Utara dengan nilai deformasi sebesar $15-30 \mathrm{~cm}$ terhadap Line of Sight (LOS). Sedangkan deformasi berupa penurunan muka tanah (subsidence) terjadi di Kota Mataram dan Lombok Barat dengan nilai -6 sampai $-16 \mathrm{~cm}$ terhadap Line of Sight (LOS). Sementara deformasi yang terjadi pasca gempa Lombok 19 Agustus 2018, menyebabkan kenaikan muka tanah (uplift) di pesisir Lombok Timur dengan nilai deformasi sebesar 18 sampai $31 \mathrm{~cm}$ terhadap Line of Sight (LOS). Sedangkan deformasi berupa penurunan muka tanah (subsidence) terjadi di Lombok Tengah dengan nilai -3 sampai $-17 \mathrm{~cm}$ terhadap Line of Sight (LOS).
\end{abstract}

Abstract. Lombok is located on the boundary of active tectonic plates, this is what caused the Lombok Earthquake on August, 2018. DInSAR is a remote sensing technology that utilizes radar satellites to measure the amount of deformation on the surface of the ground with sub-centimeter accuracy. This study aims to obtain the value of surface deformation after the earthquake that struck the Lombok region, in August 5, 2018 Earthquake and the August 192018 Earthquake and analyze impact and 
○ 2020 JGE (Jurnal Geofisika Eksplorasi). This article is an open access article distributed under the terms and conditions of the Creative Commons Attribution (CC BY NC) charateristics of the deformation that occurred in the two earthquakes. The research was carried out based on SAR Sentinel-1 image processing using SNAP Software, Google Earth and ArcGIS 10.3. Deformation that occurred after the Lombok earthquake on August 5, 2018 caused an increase in land level (uplift) on the coast of North Lombok with a deformation value of 15$30 \mathrm{~cm}$ to the Line of Sight (LOS). Whereas deformation in the form of subsidence occurs in the City of Mataram and West Lombok with a value of -6 to $-16 \mathrm{~cm}$ to the Line of Sight (LOS). While the deformation that occurred after the Lombok earthquake on August 19, 2018, caused an increase in land level (uplift) on the East Lombok coast with a deformation value of 18 to $31 \mathrm{~cm}$ to the Line of Sight (LOS). Whereas deformation in the form of subsidence occurs in Central Lombok with a value of -3 to $-17 \mathrm{~cm}$ to the Line of Sight (LOS).

\section{PENDAHULUAN}

Lombok merupakan salah satu wilayah di Indonesia yang berada di kawasan tektonik yang aktif, berdasarkan buku Pusat Studi Gempa Nasional (2018), Pulau Lombok dikelilingi oleh beberapa sumber gempa, yaitu diantaranya Zona Back Arc Thrust di wilayah utara, Megathrust di wilayah selatan dan sistem sesar geser di wilayah barat dan timurnya. Dari kondisi geografis yang ada, Pulau Lombok memiliki potensi bencana alam yang besar, terutama bencana gempabumi (Astawa dkk., 2005)

Gempa Lombok 5 Agustus 2018 dengan kekuatan 6.9 magnitudo menjadi bukti nyata betapa rawannya aktifitas tektonik di kawasan tersebut. Gempa ini bahkan tidak hanya dirasakan di Pulau Lombok saja melainkan juga dirasakan di Kepulauan Sumbawa, Bali, Jawa dan Kalimantan. Pada umumnya, informasi yang diterima oleh masyarakat masih terbatas pada parameter gempa seperti waktu kejadian, magnitudo dan lokasi pusat gempa, selain itu juga disajikan tentang kerugian materi dan korban jiwa yang ditimbulkan akibat gempa. Sementara informasi mengenai karakteristik dan dampak fisis yang ditimbulkan belum diinformasikan secara menyeluruh. Selain itu, upaya mitigasi dari bencana gempabumi dengan menggunakan metode konvensional akan membutuhkan biaya yang mahal, tenaga manusia yang intensif serta waktu yang lama.

Upaya pemantauan gempa penting dilakukan sebagai salah satu langkah untuk mitigasi dan investigasi terhadap bencana alam yang tak terduga. Berdasarkan permasalahan diatas penelitian ini berupaya untuk memberikan solusi dengan pendekatan metode DInSAR dalam pemantauan deformasi permukaan pasca terjadinya gempa yang melanda kawasan Lombok yaitu Gempa 5 Agustus 2018 dan Gempa 19 Agustus 2018 menganalisis karakteristik deformasi permukaan yang terjadi pada dua event gempa tersebut. Selain itu juga dapat digunakan untuk memberikan informasi mengenai karakteristik sebelum dan sesudah terjadinya gempa pada periode Agustus 2018 di wilayah tektonik Pulau Lombok, Nusa Tenggara Barat sebagai upaya dalam mengetahui karakteristik dan dampak fisis dari bencana gempabumi.

\section{TINJAUAN PUSTAKA}

\subsection{Lokasi Penelitian}

Lokasi penelitian seperti terlihat pada Gambar 1 berada di daerah Pulau Lombok Provinsi Nusa Tenggara Barat yang berada pada titik koordinat 8034'59" Lintang Selatan dan 
$116^{\circ} 16^{\prime} 20^{\prime \prime}$ Bujur Timur. Adapun peta lokasi penelitian yang akan diamati adalah seluruh bagian Pulau Lombok yang mengalami deformasi permukaan pasca gempabumi periode Agustus 2018.

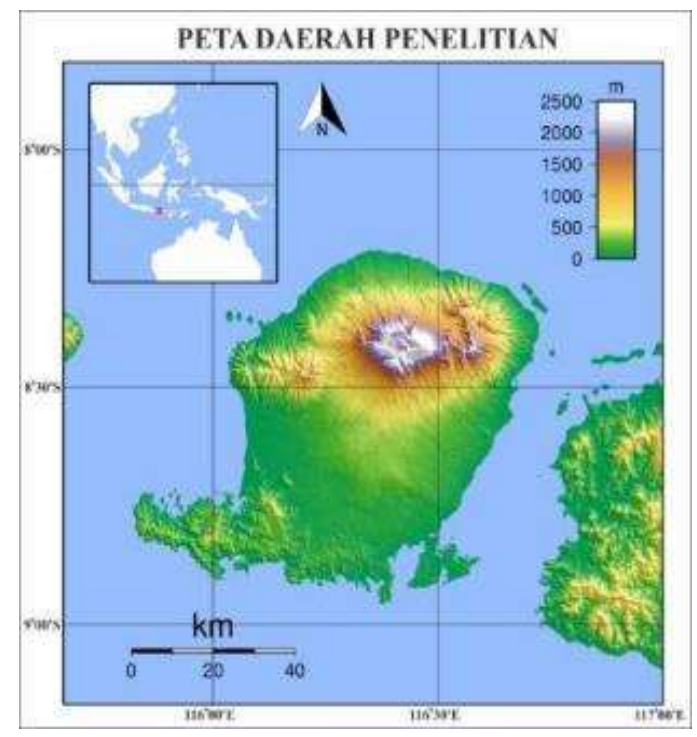

Gambar 1. Peta Pulau Lombok

\subsection{Kondisi Fisiografis dan Tektonik}

Secara fisiografi, batas kepulauan Nusa Tenggara bagian barat dibatasi oleh Pulau Jawa, di bagian timur oleh Busur Banda, di bagian utara oleh Laut Flores dan di bagian selatan oleh Samudera Indonesia. Secara geologi kepulauan ini terletak di pusat Busur Banda, yang terbentuk oleh rangkaian kepulauan gunung api muda. Sedangkan, secara tektonik rangkaian gunung ini akibat subduksi Lempeng Indo-Australia terhadap Busur Banda. Sebagian besar busur dari kepulauan Nusa Tenggara dibentuk oleh zona subduksi dari Lempeng Indo-Australia yang berada tepat di bawah Busur Sunda-Banda selama di atas kurun waktu tersier yang mana subduksi ini dibentuk di dalam busur vulkanik kepulauan Nusa Tenggara. Bagian timur Nusa Tenggara mulai dari Alor-Kambing-Wetar-Romang bisa disebut sebagai orogenik timur dengan pusat undasi di Laut Flores. Evolusi orogenik daerah Nusa Tenggara bagian timur ini cukup kompleks karena pada masa Mesozoikum muda terjadi penggelombangan yang termasuk dalam Sirkum Australia. Namun memasuki periode tersier daerah ini mengalami proses penggelombangan dengan pusat undasi di Laut Flores sebagai bagian dari sistem Pegunungan Sunda (Astawa dkk., 2005).

Selain kerawanan seismik akibat aktivitas pertemuan lempeng, Nusa Tenggara juga sangat rawan, karena adanya sebuah struktur tektonik sesar naik belakang busur kepulauan yang populer dikenal sebagai Back Arc Thrust. Struktur ini terbentuk akibat tunjaman balik Lempeng Eurasia terhadap Lempeng IndoAustralia. Fenomena tumbukan busur benua diduga sebagai pengendali mekanisme deformasi sesar naik ini (Ramdani dkk., 2019). Back Arc Thrust membujur di Laut Flores sejajar dengan Busur Kepulauan Bali dan Nusa Tenggara dalam bentuk segmen-segmen, terdapat segmen utama maupun segmen minor. Fenomena sesar naik belakang busur kepulauan ini sangat menarik untuk diteliti dan dikaji mengingat sangat aktifnya dalam membangkitkan gempa tektonik di kawasan tersebut.

Pada tahun 1978 pernah terjadi gempa dengan magnitudo 5.8 SR (MB) dengan kedalaman $12 \mathrm{~km}$. Pusat gempa dan gempa susulannya berada di sekitar ujung timur Flores Thrust. Gempa tahun 1992 tampak bergeser ke arah timur dimana pusat gempa susulannya yang dideterminasi oleh USGS berada pada wilayah yang tidak menampakkan adanya indikasi penyesaran. Fenomena ini merupakan suatu respon daerah belakang busur akibat adanya tumbukan dengan Benua Australia (Daryono, 2011).

\subsection{Deformasi}

Deformasi adalah perubahan bentuk atau ukuran suatu tubuh sebagai respon terhadap gaya (force) yang diterapkan. Selain itu deformasi juga berarti perubahan posisi (translation) dan orientasi (rotation). Gaya (force) yang dimaksud didalamnya termasuk 
body forces, misalkan gravitasi dan surfaces forces, misalnya hidrostatik (Stein \& Wysession, 2003).

Tahapan deformasi batuan secara umum terbagi menjadi tiga tahapan yaitu:

1) Elastik; setiap perubahan bentuk atau pergeseran akan kembali ke bentuk semula.

2) Ductile; perubahan bentuk yang terjadi tidak dapat kembali ke bentuk atau posisi semula.

3) Fracture; perubahan bentuk tidak dapat kembali seperti semula, melewati batas elastik dan material telah pecah (Ibrahim, 2005).

Secara umum dapat dirumuskan dengan persamaan berikut:

$$
\begin{aligned}
& \text { Tegangan }(\sigma)=\frac{F}{A} \\
& \text { Regangan }(\varepsilon)=\frac{\Delta l}{l o} \\
& \text { dengan: } \\
& \mathrm{F} \quad=\text { Gaya }(\mathrm{N}) \\
& \mathrm{A}=\text { Luas Permukaan }\left(\mathrm{m}^{2}\right) \\
& \Delta l=\text { Pertambahan Panjang }(\mathrm{m}) \\
& l o=\text { Panjang Awal }(\mathrm{m})
\end{aligned}
$$

\subsection{DInSAR}

Differential Interferometric Synthetic Aperture Radar (DInSAR) adalah teknologi penginderaan jauh yang menggunakan citra hasil dari satelit radar untuk pengamatan deformasi permukaan dengan akurasi yang tinggi pada orde sentimeter. Pada metode ini digunakan beberapa pasang interferogram untuk mendeteksi perubahan permukaan topografi dengan ketelitian yang tinggi. Pola interferensi dari 2 citra (master dan slave) SAR pada daerah yang sama, diperoleh dengan cara 2 kali lintasan pada topografi yang dicitrakan. Pada citra hasil lintasan pertama diperoleh nilai fase, begitupun dengan citra kedua pada lintasan kedua juga diperoleh nilai fase. Jika terjadi perbedaan fase antara pencitraan lintasan pertama dengan lintasan kedua, maka akan terlihat fringes (rumbai-rumbai) pada interferogram yang dinamakan displacement fringes. Pada interferogram terdapat 2 fringes utama, yaitu displacement fringes yang diakibatkan karena pergeseran permukaan topografi, kedua adalah topographic fringes yang diakibatkan bentuk topografi (Campbell \& Wynne, 2011). Tujuan utama DInSAR adalah untuk mengekstrak total fase yang hanya diakibatkan oleh deformasi dengan menghapus atau meminimalkan hal-hal lain yang berkontribusi. Apabila terdapat modul permukaan topografi yang dijadikan sebagai acuan atau apabila terdapat tiga atau lebih citra radar maka perubahan dapat ditentukan melalui differential InSAR. Informasi fase yang dimiliki oleh inteferogram dari hasil pengamatan 2 SAR pada waktu yang berbeda, sebenarnya memiliki unsur topografi, pergeseran orbit, deformasi permukaan dan efek atmosfer (Castañeda dkk., 2011).

Nilai beda fase dapat dirumuskan dengan persamaan berikut:

$$
\begin{aligned}
\Delta \emptyset= & 4 \pi \frac{\delta R}{\lambda} \\
\Delta \emptyset= & \Delta \emptyset \text { topo }+\Delta \emptyset \text { defo }+\Delta \emptyset \text { atm }+ \\
& \Delta \emptyset \text { orb }
\end{aligned}
$$

dengan:

$$
\begin{array}{ll}
\emptyset & =\text { Beda Fase } \\
\lambda & =\text { Panjang Gelombang Sentinel-1 } \\
\mathrm{R} & =\text { Jarak Objek dengan Radar } \\
\emptyset \text { topo } & =\text { Fase Topografi } \\
\emptyset \text { defo } & =\text { Fase Deformasi } \\
\emptyset a t m & =\text { Fase Atmosfer } \\
\emptyset \text { orb } & =\text { Fase Orbit }
\end{array}
$$

\subsection{Karakteristik Sentinel 1}

Sentinel-1 (Gambar 2) merupakan seri satelit pertama dari tujuh misi satelit yang diluncurkan sebagai bagian dari program Copernicus yang digagas oleh European Commission (EC) dan European Space Agency (ESA). Seperti satelit SAR ESA sebelumnya, Sentinel-1 memiliki sensor C-band dengan dua buah satelit yakni Sentinel-1A dan Sentinel-1B 
yang mengorbit secara tandem berjauhan $180^{\circ}$. Masing-masing satelit mampu melakukan repeat cycle setiap 12 hari dan dengan konstelasi kedua satelit tersebut membuat Sentinel-1 memiliki repeat cycle setiap 6 hari. Sentibel-1 memiliki 4 mode pengamatan dengan mode utama di daratan adalah mode Interferometric Wide swath (IW) dengan resolusi spasial sekitar 5 m x 20 m (Fakhri Islam dkk., 2017).

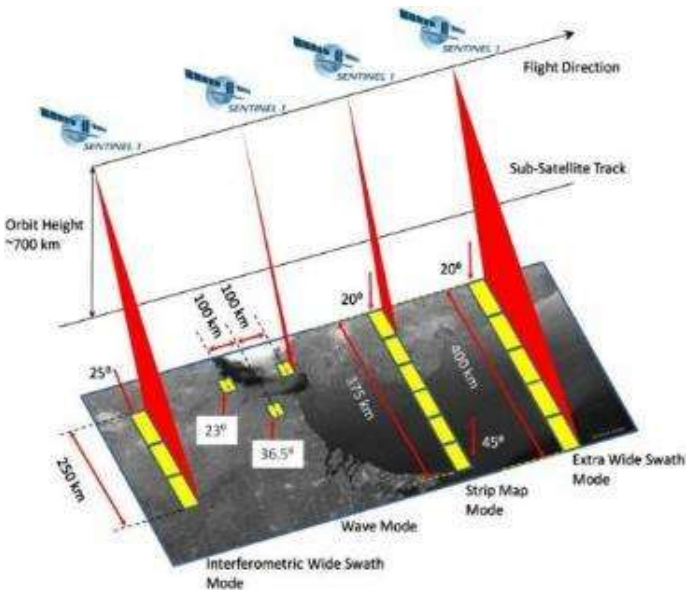

Gambar 2. Satelit Sentinel-1 (European Space Agency (ESA), 2016)

Sentinel-1 memiliki 4 mode standar operasional yang didesain untuk interoperabilitas dengan sistem lainnya:

a) Mode Strip Map, swat $80 \mathrm{~km}$ dan resolusi spasial $5 \times 5$ meter.

b) Interferometric Wide Swath Mode, $250 \mathrm{~km}$ swath, 5 x 20 m spatial resolution dan sinkronisasi interferometri.

c) Extra-wide Swath Mode, $400 \mathrm{~km}$ swath dan $25 \times 100 \mathrm{~m}$ spatial resolution.

d) Wave Mode, low data rate dan $5 \times 20 \mathrm{~m}$ spatial resolution. Contoh gambar pada 20 x $20 \mathrm{~km}$ pada interval $100 \mathrm{~km}$ sepanjang orbit (ESA, 2016).

\section{METODOLOGI PENELITIAN}

Data yang digunakan dalam penelitian ini terdiri dari dua pasang data citra SAR Sentinel 1A dan 1B yang diperlukan dalam pengolahan citra untuk menganalisis deformasi yang terjadi pasca gempabumi Lombok 5 Agustus 2018 dan
19 Agustus 2018. Pengambilan data gempa ini didasarkan pada besarnya kekuatan gempa dengan magnitudo lebih dari 6.5 dan kedalaman kurang dari $60 \mathrm{~km}$ Data DEMSRTM $30 \mathrm{~m}$ juga digunakan dalam penelitian ini dimana data ini memiliki sistem koordinat geografis, sedangkan untuk pemrosesan DInSAR dilakukan pada sistem koordinat radar, sehingga perlu dilakukan proses transformasi koordinat dari sistem koordinat geografis pada DEM-SRTM $30 \mathrm{~m}$ menjadi sistem koordinat kartesian sistem radar (range dan azimuth).

Adapun perangkat lunak yang digunakan dalam penelitian ini yaitu:

a) Software SNAP, sebagai perangkat lunak pengolahan data citra SAR Sentinel-1 dan visualisasi data.

b) Software Google Earth, sebagai perangkat lunak untuk visualisasi data hasil penelitian pada permukaan bumi secara virtual.

c) Software ArcGIS versi 10.3 untuk melakukan operasi data raster, vektor serta representasi data.

Proses pengolahan data diatas sebagian besar dilakukan dengan menggunakan software utama pengolah data Sentinel-1 yaitu Software SNAP. Sedangkan Software Google Earth dan ArcGIS 10.3 digunakan untuk visualisasi dan representasi data. Output akhir yang dihasilkan dalam proses ini adalah peta deformasi permukaan pasca terjadinya gempa pada tanggal 5 Agustus 2018 dan 19 Agustus 2018.

\section{HASIL DAN PEMBAHASAN}

\subsection{Phase Interferogram}

Citra interferogram terbentuk dari hasil gabungan dua data citra SAR (master dan slave) hasil proses koregistrasi. Pada tahapan interferogram generation, pola deformasi masih dalam satuan radian (satuan sudut fase) dalam rentang $-\pi$ sampai dengan $\pi$, sehingga akan menimbulkan masalah ambiguitas. Untuk fase 
interferogram, dapat dilihat bahwa dari interferogram yang dihasilkan terdapat fringes yang terbentuk, karena orbit yang tidak sama persis pada saat pengambilan citra SAR. Fringes yang dihasilkan pada interferogram merupakan garis-garis tipis yang menunjukkan besar fase pada nilai yang sama. Dimana besar fase didapatkan dari adanya perambatan gelombang elektromagnetik yang melewati media atmosfer dari satelit kepada objek (Thomas, 2020). Pada tahapan interferogram generation, fringes yang terbentuk pada interferogram belum bisa menggambarkan deformasi secara jelas, oleh karena itu perlu dilakukan proses image filtering.

\subsection{Phase Filtering}

Proses filtering merupakan tahapan pengolahan data yang bertujuan untuk menaikkan nilai SNR (Single Noise Ratio) pada interferogram disebabkan oleh pengaruh dari penjalaran sinyal kembali ke medium udara atau atmosfer sehingga menghilangkan dekorelasi yang diakibatkan oleh efek noise dan orbit yang menyebabkan menurunnya kualitas

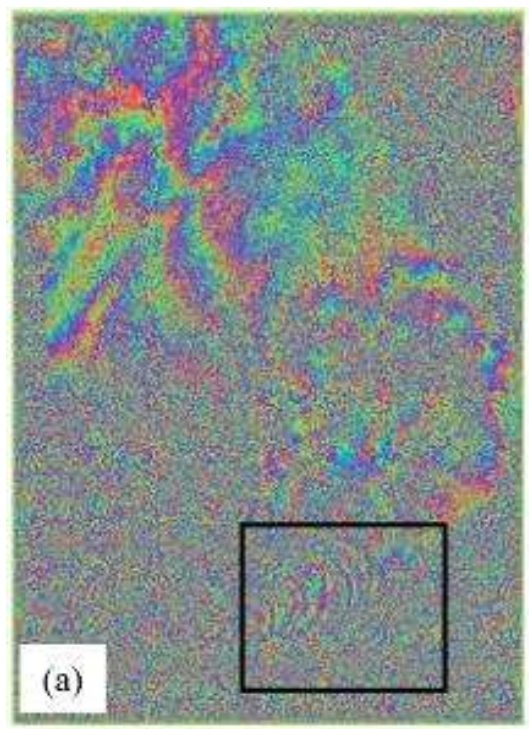

Phase_Ifg_WV_02Aug2018_08Aug2018 [phase]

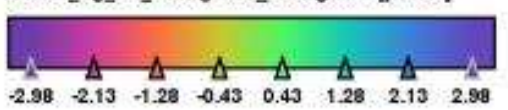

Gambar 3. Citra Interferogram Gempa 5 Agustus 2018 (a) Sebelum Filtering (b) Setelah Filtering

citra SAR, menaikkan nilai akurasi dan mempertajam fase di area-area yang nilai koherensinya masih relatif besar (Monterroso dkk., 2018). Operasi filtering ini juga dilakukan untuk menghilangkan speckle yang terdapat pada citra interferogram. Adapun menaikkan nilai SNR merupakan salah satu cara yang dapat digunakan untuk proses pemfilteran citra SAR.

Proses filtering yang dilakukan dengan menggunakan Software SNAP dengan waktu yang cukup cepat. Hasil phase sebelum dan sesudah dapat dilihat pada Gambar 3 dimana pada kotak berwarna hitam merupakan contoh wilayah pada interferogram yang mengalami perubahan setelah dilakukan adanya filtering. Perubahan dapat dilihat dari fringes pada interferogram setelah proses filtering memiliki tingkat visibilitas yang lebih baik. Hasil yang didapatkan ini sesuai dengan penelitian Goldstein dan Werner (1998) yang menunjukkan bahwa proses filtering secara signifikan dapat meningkatkan visibilitas fringes yang ada pada inteferogram.

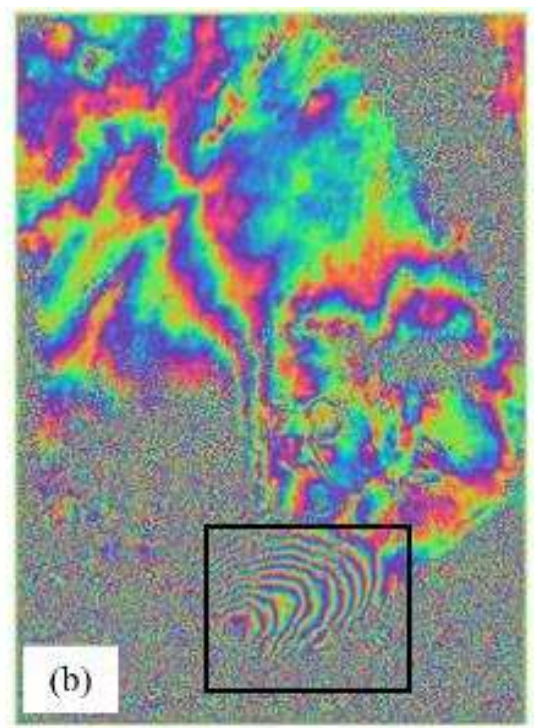




\subsection{Koherensi Citra SAR}

Citra interferogram yang dihasilkan oleh proses InSAR memiliki tingkat koherensi yang berbeda-beda (Gambar 4). Koherensi ini merupakan nilai yang digunakan untuk mengestimasi phase noice dari citra interferogram. Tingkat koherensi pada citra interferogram memiliki kisaran nilai antara 0-1. Dimana nilai 1 merupakan tingkat koherensi yang paling tinggi sehingga pasangan citra benar-benar identik dan memiliki informasi yang akurat berdasarkan kualitas citra

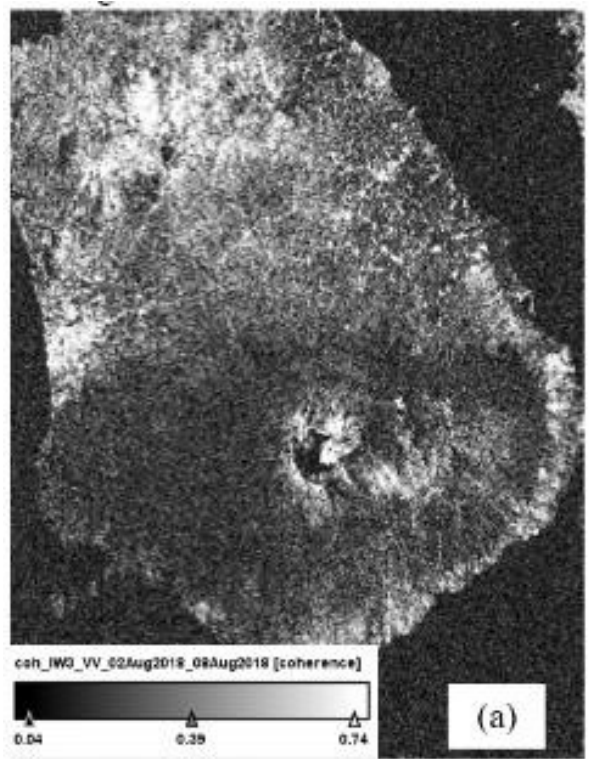

Gambar 4. Koherensi Citra SAR Gempa 5 Agustus 2018 (b) Gempa 19 Agustus 2018

Untuk event Gempa 5 Agustus 2018, daerah dengan memiliki nilai koherensi tinggi (mendekati 1) berada pada daerah Lombok Utara, Lombok Tengah, Kota Mataram dan kawasan Gunung Rinjani dengan rentang nilai koherensi 0.6-0.8, sedangkan persebaran nilai koherensi rendah berada pada daerah Lombok Barat dan sebagian di Lombok Tengah dan Utara dengan rentang nilai 0.1-0.3. Rendahnya koherensi ini, karena pada citra interferogram yang sebagian besar area di Lombok Barat dan Lombok Utara memiliki kerapatan vegetasi yang tinggi. Untuk event Gempa 19 Agustus 2018, daerah yang memiliki nilai koherensi interferogram. Sedangkan nilai 0 menyatakan tidak ada informasi pada citra interferogram yang dihasilkan karena berbagai faktor, salah satunya ialah banyaknya phase noise yang tertangkap oleh satelit radar. Nilai koherensi yang didapatkan di daerah Pulau Lombok memiliki sebaran nilai yang bervariasi. Event Gempa Lombok tanggal 5 Agustus 2018 juga memiliki perbedaan nilai koherensi pada masing-masing titik yang terdampak oleh gempa dengan waktu yang berbeda.

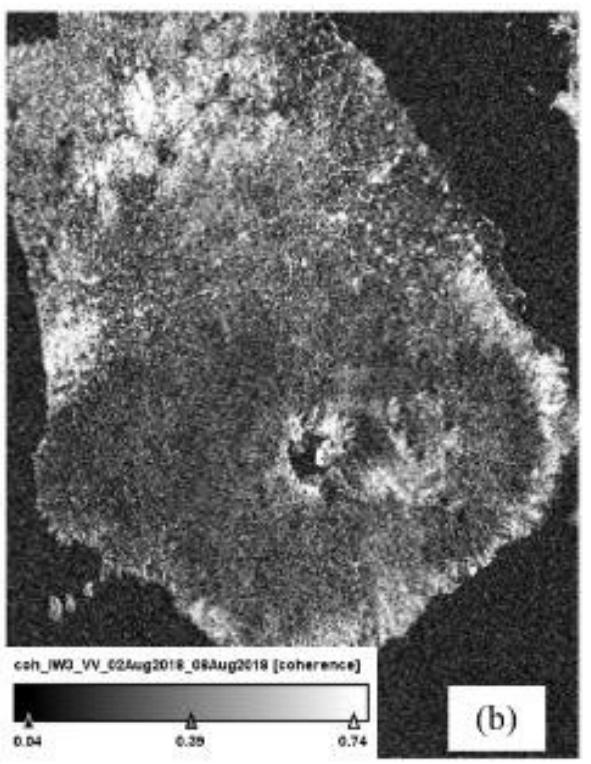

tinggi (mendekati 1) berada pada daerah pesisir Lombok Timur, Lombok Tengah, Kota Mataram dan kawasan Gunung Rinjani dengan rentang nilai koherensi $0.5-0.8$, sedangkan persebaran nilai koherensi rendah berada pada daerah Lombok Barat dengan nilai 0.1-0.3. Rendahnya koherensi ini karena pada citra interferogram yang sebagian besar area di Lombok Barat memiliki kerapatan vegetasi yang tinggi. Kerapatan vegetasi ini akan mempengaruhi nilai koherensi citra karena pergerakan dan perubahan vegetasi akan berpengaruh pada pantulan backscatter-nya (Sari dkk., 2014). 
Selain itu juga, rendahnya nilai koherensi pada citra interferogram juga dapat disebabkan karena adanya ketidakcocokan sifat dari dua sistem pencitraan yang terlibat dikarenakan adanya volume scattering error pada saat pemrosesan. Pada wilayah vegetasi, dekorelasi temporal akan menyebabkan penurunan nilai koherensi (Bakon dkk., 2014). Menurut hasil penelitian yang dilakukan oleh Monterroso dkk. (2018) mengindikasikan bahwa koherensi pada Band-C secara signifikan lebih rendah pada area vegetasi dibandingkan urban area dikarenakan interval waktu 12 hari pada pengambilan citra Sentinel-1 dianggap lama jika dibandingkan dengan ERS-1 yang interval waktu pengambilan citra hanya 3 hari saja. Penelitian yang ditunjukkan oleh $\mathrm{He}$ dkk. (2019) juga menunjukkan bahwa penggunaan Band-C memiliki penggunaan yang terbatas, seperti pembentukan interferogram yang tidak terlalu berguna akibat rendahnya nilai koherensi. Tetapi Band-C yang memiliki panjang gelombang lebih pendek daripada $B a n d-L$, lebih sensitif terhadap perubahan yang kecil (Fournier dkk., 2010).

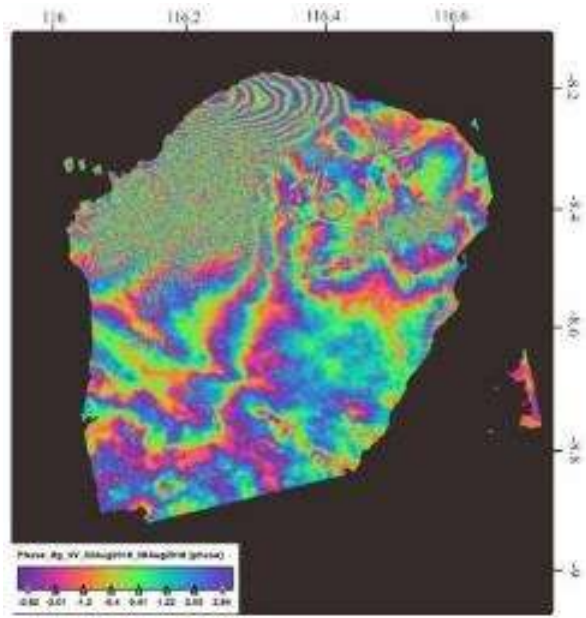

\subsection{Phase Unwrapping}

Phase Unwrapping merupakan proses penambahan nilai kelipatan bilangan bulat (integer) dari $2 \pi$ ke fringes yang ada pada interferogram. Hal ini disebabkan adanya variasi fase antara 2 titik pada interferogram hasil pendataran (flattened interferogram) menyediakan pengukuran variasi ketinggian aktual, setelah menghapus setiap bilangan bulat pada nilai ambiguitas. Setelah melalui proses unwrapping, citra inteferogram sudah dapat diketahui nilai deformasinya dalam fase absolut atau satuan metrik sehingga memudahkan dalam proses interpretasi dari sebaran nilai deformasi permukaan hasil olahan citra yang lebih terukur dan akurat. Dalam proses phase unwrapping juga diperlukan koreksi medan (train correction) untuk menghilangkan efek topografi di permukaan serta menkonversi koordinat slant range ke dalam koordinat kartografik sehingga dapat diketahui secara pasti letak dan posisinya di permukaan bumi. Gambar 5 merupakan interferogram yang telah dilakukan train correction.

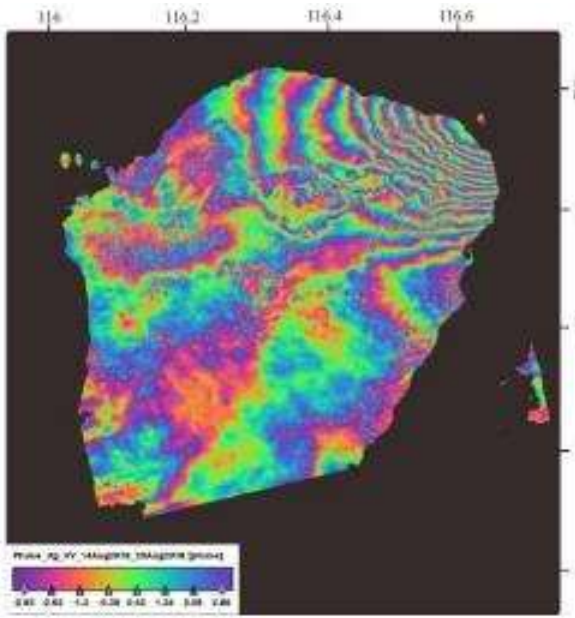

Gambar 5. Citra Interferogram Setelah Train Correction gempa 5 Agustus 2018 (kiri) dan gempa 19 Agustus 2018 (kanan)

Berdasarkan hasil phase unwrapping yang ada pada Gambar 6, dapat dilihat bahwa secara umum pola deformasi menjadi terlihat lebih jelas dan terukur dalam satuan metrik. Pada bagian permukaan Pulau Lombok tidak semua wilayah mengalami displacement. Banyaknya piksel yang kosong pada wilayah permukaan Pulau Lombok menyebabkan sulitnya 
pembacaan besar deformasi karena pada proses filtering dan unwrapping, nilai koherensi yang rendah telah dihilangkan. Adapun koherensi data yang digunakan dalam penelitian ini berada pada rentang nilai koherensi lebih dari 0.4 , sedangkan nilai koherensi yang kurang dari 0.4 telah dihilangkan guna mereduksi data yang terkontaminasi dengan noise, scattering error atau kerapatan vegetasi yang tinggi. Pemilihan

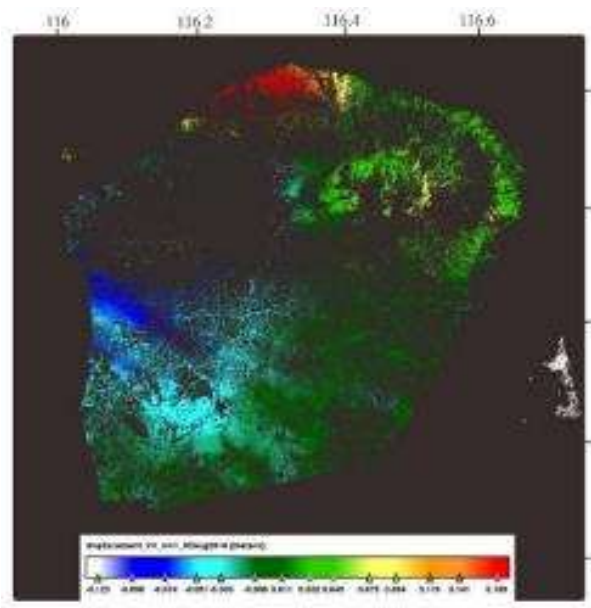

Gambar 6. Citra SAR Setelah Proses Unwrapping gempa 5 Agustus 2018 (kiri) dan gempa 19 Agustus 2018 (kanan)

\subsection{Analisis Deformasi Permukaan}

Dalam penelitian ini diperoleh sebaran nilai deformasi permukaan di wilayah Lombok, Nusa Tenggara Barat pasca terjadinya Gempa 5 Agustus 2018. Berdasarkan model deformasi permukaan tidak semua wilayah pulau Lombok mengalami deformasi yang signifikan pasca terjadinya gempa. Hasil yang diperoleh (Gambar 7) menunjukkan nilai deformasi berupa kenaikan permukaan tanah (uplift) yang berada pada daerah Lombok Utara di dekat pesisir dengan rentang nilai deformasi 15-30 $\mathrm{cm}$. Sedangkan untuk deformasi yang mengakibatkan terjadinya penurunan muka tanah (subsidence) terdapat pada daerah Lombok Tengah, Lombok Barat dan Kota Mataram dengan nilai -6 sampai dengan $-16 \mathrm{~cm}$ terhadap Line of Sight (LOS).

Sedangkan untuk event Gempa 19 Agustus 2018 diperoleh sebaran nilai deformasi permukaan yang berbeda (Gambar 7). Jika

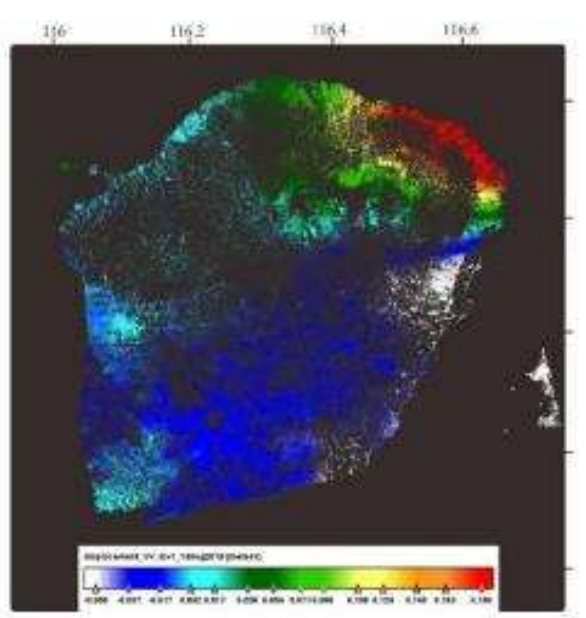

batas nilai koherensi 0.4 ini didasarkan pada nilai statistik koherensi pada seluruh interferogram, dimana jika digunakan batas nilai koherensi lebih dari 0.4 akan lebih banyak null value (informasi yang hilang) dan jika digunakan filtering dengan nilai koherensi yang kurang dari 0.4 akan mengurangi Single Noise Ratio (SNR) pada fase interferogram.

dibandingkan dengan gempa utama sebelumnya, hasil yang diperoleh pada event gempa ini menunjukan deformasi berupa kenaikan permukaan tanah (uplift) dominan bergeser ke arah Lombok Timur didekat pesisir dengan rentang nilai deformasi $18-31 \mathrm{~cm}$ terhadap Line of Sight (LOS). Sedangkan untuk deformasi yang mengakibatkan terjadinya penurunan permukaan tanah (subsidence) terdapat pada daerah Lombok Tengah dengan rentang nilai -3 sampai $-17 \mathrm{~cm}$. Penurunan muka tanah pasca gempa di daerah ini disebabkan karena daerah Lombok Tengah merupakan kawasan padat penduduk, industri serta daerah pusat ekonomi sehingga potensi tekanan bangunan terhadap permukaan tanah akan semakin tinggi. Jika Pulau Lombok yang terdeformasi pasca gempa dilakukan analisis nilai deformasi berdasarkan klaster maka dapat diperoleh grafik perbandingan antara kedua event gempa. 

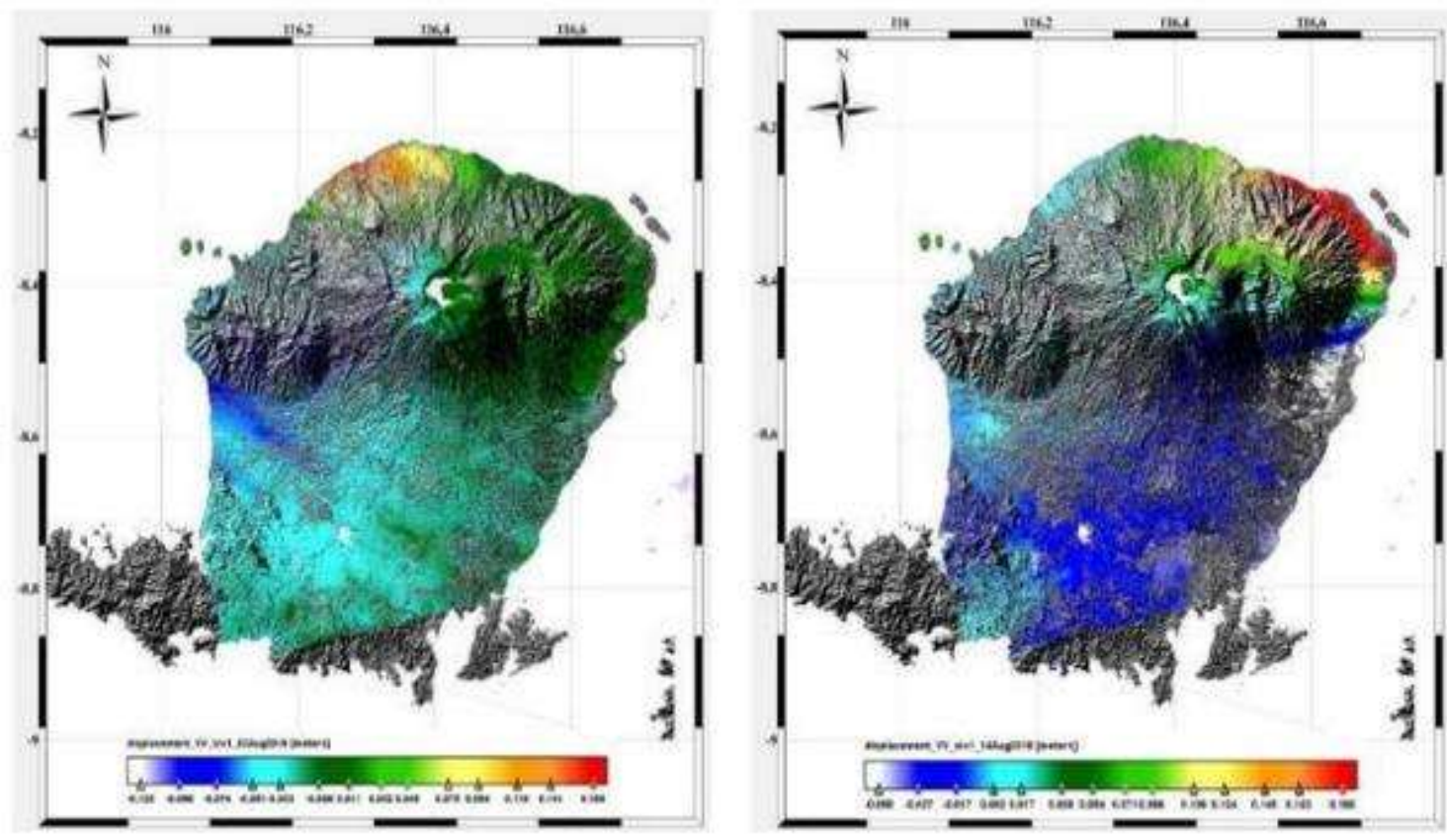

Gambar 7. Peta Deformasi \& DEM SRTM Lombok gempa 5 Agustus 2018 (kiri) dan gempa 19 Agustus 2018 (kanan)

\subsubsection{Grafik Wilayah Lombok Utara}

Berdasarkan grafik nilai deformasi (Gambar

8) pasca gempa Lombok periode Agustus 2018 didapatkan sebaran nilai deformasi khususnya di wilayah Lombok Utara. Pada event gempa 5 Agustus 2018 telah terjadi deformasi berupa kenaikan muka tanah (uplift) terhadap Line of Sight (LOS) dengan rentang nilai $15-30 \mathrm{~cm}$. Hal serupa juga terjadi pada event gempa 19 Agustus 2018 dimana berdasarkan hasil pengolahan data didapatkan deformasi berupa kenaikan muka tanah (uplift) dengan rentang nilai 5-10 cm. Jika membandingkan hasil deformasi yang terjadi pada event gempa 5 Agustus 2018 lebih besar daripada event gempa 19 Agustus 2018, hal ini dikarenakan pada event gempa 5 Agustus 2018 merupakan gempa yang episenternya berpusat di daerah Lombok Utara, sehingga mengakibatkan daerah di sekitarnya mengalami deformasi serta kerusakan yang dominan terjadi di Kecamatan Bayan, Kayangan, Pemenang dan Tanjung mengalami kenaikan muka tanah yang cukup signifikan.

\subsubsection{Grafik Wilayah Lombok Timur}

Berdasarkan grafik nilai deformasi (Gambar 9) pasca gempa Lombok periode Agustus 2018 didapatkan sebaran nilai deformasi khususnya di wilayah Lombok Timur. Pada event gempa 5 Agustus 2018 telah terjadi deformasi berupa kenaikan muka tanah (uplift) terhadap Line of Sight (LOS) dengan nilai $2-5 \mathrm{~cm}$. Hal serupa juga terjadi pada event Gempa 19 Agustus 2018 dimana berdasarkan hasil pengolahan data didapatkan deformasi berupa kenaikan muka tanah (uplift) dengan nilai $18-31 \mathrm{~cm}$. Jika membandingkan hasil deformasi yang terjadi pada Gempa 19 Agustus 2018 lebih besar daripada Gempa 5 Agustus 2018, hal ini disebabkan karena pada event Gempa 5 Agustus 2018 merupakan gempa yang episenternya berpusat di daerah Lombok Timur, hal ini mengakibatkan daerah di sekitarnya mengalami deformasi yang dominan terjadi di pesisir Lombok Timur dan Kawasan Sambelia yang mengalami kenaikan cukup signifikan bahkan cakupan wilayah yang terdampak lebih 
besar dibandingkan gempa 5 Agustus 2018 yang berpusat di Lombok Utara.

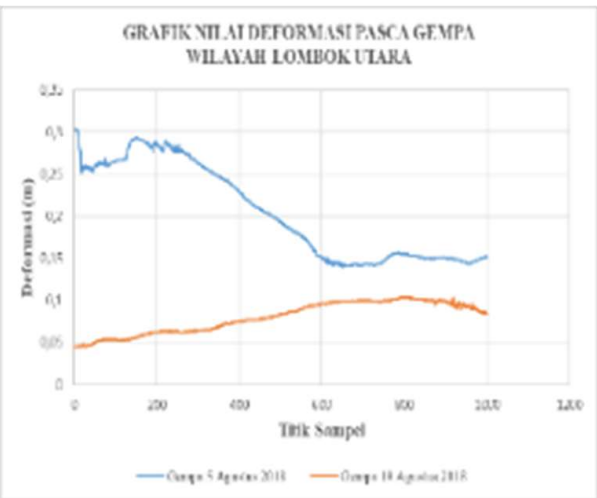

Gambar 8. Grafik Nilai Deformasi Lombok Utara

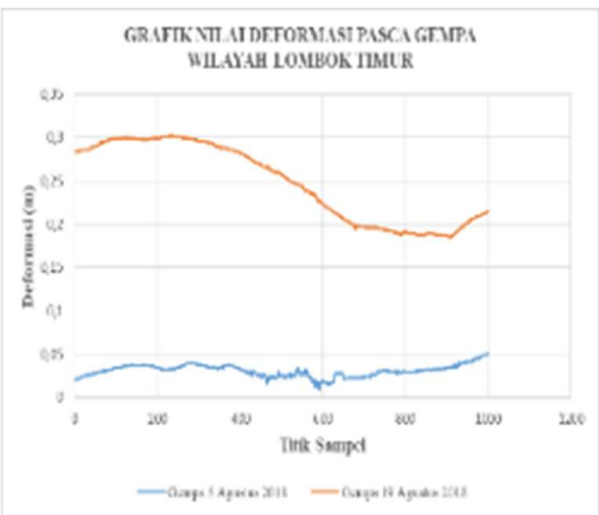

Gambar 9. Grafik Nilai Deformasi Lombok Timur

\subsubsection{Grafik Wilayah Lombok Barat}

Berdasarkan Gambar 10. hasil yang didapatkan pada event gempa 5 Agustus 2018 telah terjadi deformasi berupa penurunan muka tanah (subsidence) terhadap Line of Sight (LOS) dengan nilai -6 sampai $-16 \mathrm{~cm}$. Hal serupa juga terjadi pada gempa 19 Agustus 2018, berdasarkan hasil pengolahan data didapatkan deformasi berupa penurunan muka tanah (subsidence) dengan nilai -2 sampai $-3 \mathrm{~cm}$. Jika membandingkan dengan hasil deformasi (subsidence) yang terjadi pada gempa 5 Agustus 2018 lebih besar daripada gempa 19 Agustus 2018, hal ini diduga karena pada event gempa 5 Agustus 2018 memiliki pola pergesaran strain ke arah barat daya, hal ini mengakibatkan daerah di sekitarnya mengalami deformasi yang dominan terjadi di pesisir Lombok Barat, Gunung Sari, Lingsar, Batu Layar dan Gerung.
Selain itu, faktor kawasan padat penduduk di Lombok Barat menjadikan daerah ini mengalami deformasi penurunan muka tanah (subsidence) yang cukup signifikan.

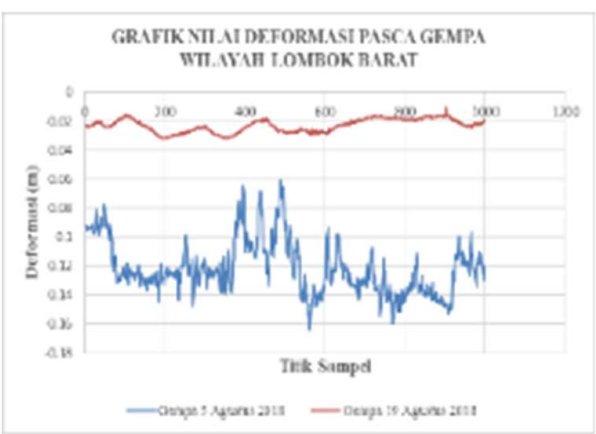

Gambar 10. Grafik Nilai Deformasi Lombok Barat

\subsubsection{Grafik Wilayah Kota Mataram}

Berdasarkan (Gambar 11) hasil yang didapatkan pada event gempa 5 Agustus 2018 telah terjadi deformasi berupa penurunan muka tanah (subsidence) terhadap Line of Sight (LOS) dengan nilai -6 sampai $-9 \mathrm{~cm}$. Hal serupa juga terjadi pada event Gempa 19 Agustus 2018, berdasarkan hasil pengolahan data didapatkan deformasi berupa penurunan muka tanah (uplift) dengan rentang nilai -2 sampai $-3 \mathrm{~cm}$. Jika membandingkan dengan hasil deformasi (subsidence) yang terjadi pada event Gempa 5 Agustus 2018 lebih besar daripada event Gempa 19 Agustus 2018, hal ini diduga karena pada event Gempa 5 Agustus 2018 memiliki pola pergesaran sesar ke arah Barat Daya, hal ini mengakibatkan daerah di sekitarnya mengalami deformasi yang dominan terjadi hampir di seluruh wilayah darat dan pesisir Kota Mataram. Selain itu, faktor kawasan padat penduduk di Kota Mataram menjadikan daerah ini mengalami deformasi penurunan muka tanah (subsidence) yang cukup signifikan.

\subsubsection{Grafik Wilayah Gunung Rinjani}

Berdasarkan (Gambar 12) hasil yang didapatkan pada event gempa 5 Agustus 2018 telah terjadi deformasi kenaikan muka tanah (uplift) terhadap Line of Sight (LOS) dengan nilai 2-8 cm, selain itu juga terjadi penurunan muka tanah (subsidence) di sebelah barat Danau 
Segara Anak dengan nilai deformasi mencapai $4 \mathrm{~cm}$. Sedangkan pada event gempa 19 Agustus 2018, berdasarkan hasil pengolahan data diperoleh deformasi berupa kenaikan muka tanah (uplift) dengan nilai $2-8 \mathrm{~cm}$ yang terjadi di kawasan Rinjani dan Danau Segara Anak. Jika membandingkan hasil deformasi yang terjadi pada event gempa 19 Agustus 2018 hanya mengalami deformasi secara uplift sedangkan pada event gempa 5 Agustus 2018 mengalami deformasi subsidence dan uplift, hal ini diduga karena pada event gempa 5 Agustus 2018 telah terjadi longsoran tanah di sebelah barat Danau Segara Anak dari hasil pergeseran strain yang cenderung bergerak ke arah barat daya dari pusat gempa.

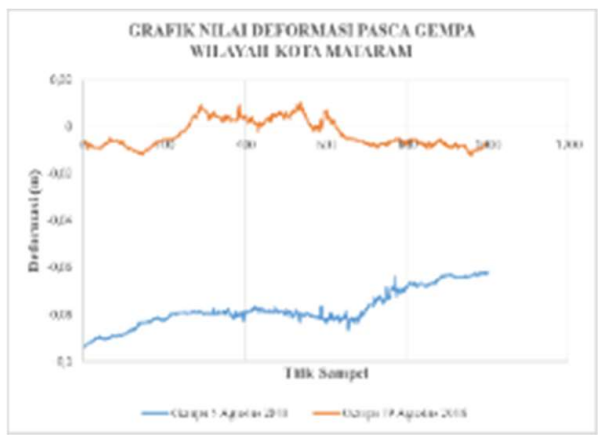

Gambar 11. Grafik Nilai Deformasi Mataram

\subsubsection{Grafik Wilayah Lombok Tengah}

Berdasarkan (Gambar 13) hasil yang didapatkan pada event empa 5 Agustus 2018 telah terjadi deformasi berupa penurunan muka tanah (subsidence) terhadap Line of Sight (LOS) dengan rentang nilai -2 sampai $-5 \mathrm{~cm}$. Hal serupa juga terjadi pada event gempa 19 Agustus 2018 dimana berdasarkan hasil pengolahan data didapatkan deformasi berupa penurunan muka tanah (subsidence) dengan nilai -1 sampai $-3 \mathrm{~cm}$. Deformasi subsidence ini dominan terjadi di Kecamatan Praya, Batukliang, Janapria, Jonggat, Kopang, Pringgarata.

Jika membandingkan dengan hasil observasi visual yang dilakukan oleh tim Pusgen, BPPT dan LIPI (2018) diperoleh temuan berupa batuan koral mikroatol yang terangkat setinggi
$36 \mathrm{~cm}$ di wilayah pesisir Lombok Utara tepatnya di daerah Kayangan-Bayan, serta terjadi penurunan muka tanah (subsidence) di daerah pesisir Lombok Barat (Pusat Studi Gempa Nasional, 2018).

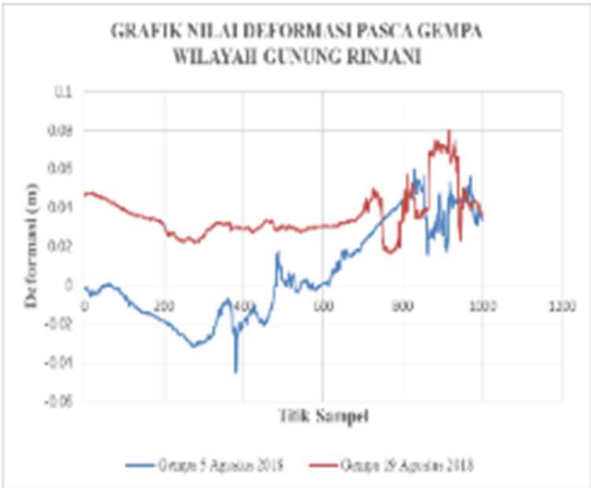

Gambar 12. Grafik Nilai Deformasi Gunung Rinjani

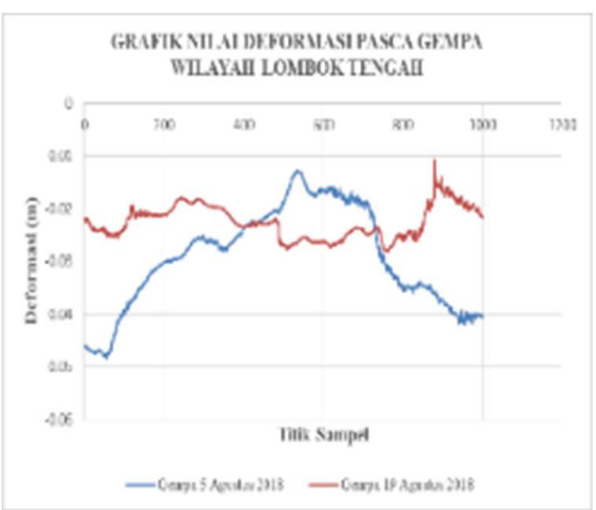

Gambar 13. Grafik Nilai Deformasi Lombok Tengah

Dominasi kenaikan muka tanah (uplift) telah terjadi pada daerah yang dekat dengan pusat gempa/sesar (Sesar Naik Flores) di pesisir utara dan timur Pulau Lombok yang diduga merupakan bidang hangingwall sesarnya sedangkan bidang footwall terdapat pada wilayah Lombok Tengah. Lombok Barat dan Kota Mataram merupakan daerah yang cenderung mengalami penurunan muka tanah (subsidence) yang disebabkan adanya faktor urban area yang padat menjadikan daerah tersebut mengalami penurunan muka tanah yang cukup signifikan. Perubahan tata guna lahan cukup signifikan pada sekitar tahun 2018. 


\section{KESIMPULAN}

Berdasarkan hasil analisis yang telah dilakukan, deformasi yang terjadi pasca Gempa Lombok 5 Agustus 2018 menyebabkan kenaikan muka tanah (uplift) di pesisir Lombok Utara dengan nilai deformasi sebesar $15-30 \mathrm{~cm}$, sedangkan deformasi berupa penurunan muka tanah (subsidence) terjadi di Kota Mataram dan Lombok Barat dengan nilai -6 sampai $-16 \mathrm{~cm}$ terhadap Line of Sight (LOS). Sementara deformasi yang terjadi pasca Gempa Lombok 19 Agustus 2018 menyebabkan kenaikan muka tanah (uplift) di pesisir Lombok Timur yang dekat dengan pusat gempa dengan nilai deformasi sebesar 18-31 cm, sedangkan deformasi berupa penurunan muka tanah (subsidence) terjadi di Lombok Tengah dengan nilai -3 sampai $-17 \mathrm{~cm}$ terhadap Line of Sight (LOS). Dari kedua event gempa menunjukan perbedaan sebaran nilai deformasi yang diakibatkan oleh adanya pergeseran strain pada sesar dengan pusat gempa yang berbeda, dimana pada event Gempa 5 Agustus 2018 berpusat di pesisir Lombok Utara sedangkan pada event Gempa 19 Agustus 2018 terjadi di pesisir Lombok Timur. Metode DInSAR ini menunjukan hasil yang konsisten dengan dampak yang terjadi di lapangan. Metode dan hasil penelitian ini juga bisa menjadi salah satu referensi untuk pemantauan dan pemulihan berdasarkan basis data historis gempa yang terjadi di kawasan Lombok.

\section{DAFTAR PUSTAKA}

Astawa, N., Ilahude, D., \& Kusnida, D. (2005). Seismik Stratigrafi Perairan Lombok Lembar Peta 1807, Nusa Tenggara Barat. JURNAL GEOLOGI KELAUTAN, 3(3). https://doi.org/10.32693/jgk.3.3.2005.127

Bakon, M., Perissin, D., Lazecky, M., \& Papco, J. (2014). Infrastructure Non-linear Deformation Monitoring Via Satellite Radar Interferometry. Procedia Technology, 16, 294-300. https://doi.org/10.1016/j.protcy.2014.10.095
Campbell, J. B., \& Wynne, R. H. (2011). Introduction to Remote Sensing (5 ed.). The Guilford Press.

Castañeda, C., Pourthie', N., \& Souyris, J.-C. (2011). Dedicated SAR interferometric analysis to detect subtle deformation in evaporite areas around Zaragoza, NE Spain. International Journal of Remote Sensing, 32(7), 1861-1884. https://doi.org/10.1080/01431161003631584

Daryono. (2011). Identifikasi Sesar Naik Belakang Busur ( Back Arc Thrust ) Daerah Bali Berdasarkan Seismisitas dan Solusi Bidang Sesar. Artikel Kebumian, Badan Meteorologi Klimatologi dan Geofisika.

European Space Agency (ESA). (2016). Sentinel-1 Satellite Description.

https://sentinel.esa.int/web/sentinel/missions/se ntinel-1/satellite-description

Fakhri Islam, L. J., Prasetyo, Y., \& Sudarsono, B. (2017). Analisis Penurunan Muka Tanah (Land Subsidence) Kota Semarang Menggunakan Citra Sentinel-1 Berdasarkan Metode Dinsar Pada Perangkat Lunak Snap. Jurnal Geodesi Undip, 6(2).

Fournier, T. J., Pritchard, M. E., \& Riddick, S. N. (2010). Duration, magnitude, and frequency of subaerial volcano deformation events: New results from Latin America using InSAR and a global synthesis. Geochemistry, Geophysics, Geosystems, 11(1). https://doi.org/10.1029/2009GC002558

Goldstein, R. M., \& Werner, C. L. (1998). Radar interferogram filtering for geophysical applications. Geophysical Research Letters, 25(21), 4035-4038. https://doi.org/10.1029/1998GL900033

He, P., Wen, Y., Xu, C., \& Chen, Y. (2019). Complete three-dimensional near-field surface displacements from imaging geodesy techniques applied to the 2016 Kumamoto earthquake. Remote Sensing of Environment, 232, 111321. https://doi.org/10.1016/j.rse.2019.111321

Ibrahim, G. (2005). Pengetahuan Seismologi. Badan Meteorologi dan Geofisika.

Monterroso, F., Luca, C. de, Bonano, M., Lanari, R., Manunta, M., Manzo, M., Zinno, I., \& Casu, F. (2018). Automatic generation of co-seismic displacement maps by using Sentinel-1 interferometric SAR data. Procedia Computer Science, 138, 332-337. 
https://doi.org/10.1016/j.procs.2018.10.047

Pusat Studi Gempa Nasional. (2018). Peta Sumber dan Bahaya Gempa Indonesia Tahun 2017. Pusat Penelitian dan Pengembangan Perumahan dan Permukiman.

Ramdani, F., Setiani, P., \& Setiawati, D. A. (2019). Analysis of sequence earthquake of Lombok Island, Indonesia. Progress in Disaster Science, 4, 100046.

https://doi.org/10.1016/j.pdisas.2019.100046

Sari, A. R., Handayani, H. H., \& Agustan, A. (2014). Penerapan Metode Dinsar untuk Analisa Deformasi Akibat Gempa Bumi dengan Validasi
Data Gps Sugar (Studi Kasus: Kepulauan Mentawai, Sumatera Barat). Geoid. https://doi.org/10.12962/j24423998.v10i1.686

Stein, S., \& Wysession, M. (2003). An Introduction to Seismology, Earthquakes and Earth Structure. Blackwell Publishing.

Thomas, A. (2020). Mapping of surface deformation associated with the 5.2 magnitude Stilfontein earthquake of 3 April 2017 using radar interferometry. The Egyptian Journal of Remote Sensing and Space Science.

https://doi.org/10.1016/j.ejrs.2020.01.005 